\title{
Working Capital Management of Small Scale Industries in Rajasthan
}

\author{
Bashar Matarneh \\ Department of Business Administration, Delmon University \\ Exhibition Avenue Manama, Kingdom of Bahrain, P.O. Box 2469 \\ Tell:+97-339-088-100Ｅ-mail: b_mata10@hotmail.com
}

Received: February 1, 2012

Accepted: March 5, 2012 Published: April 15, 2012

doi:10.5430/ijfr.v3n2p78

URL: http://dx.doi.org/10.5430/ijfr.v3n2p78

\begin{abstract}
Small scale industry (SSI) plays an important role in the economy of the state Rajasthan of India. In spite of all the odds, the SSI sector has emerged as India's engine of growth in the new millennium. The SSI sector in India contribute almost $40 \%$ of the gross industrial value added, the study is undertaken by taking 5 years data from secondary source. From this study, it has been found the working capital management is to decide the pattern of financing of the current assets, which is one of the biggest problems of working capital management. The SSIs has to decide about the sources of funds which can be avail to make investment in the current assets. The problem of working capital management of small-scale industries is not new.
\end{abstract}

Keywords: Importance of Working Capital, Growth of Current Assets Structure of working Capital, Effectiveness of Working Capital

\section{Introduction}

Small-scale industry (SSI) plays an important role in the economy of the state Rajasthan of India. In spite of all the odds, the SSI sector has emerged as India's engine of growth in the new millennium. The SSI sector in India contribute almost $40 \%$ of the gross industrial value added, $45 \%$ of the total export and is the second largest employers of human recourses after agriculture in India as well as in the state of Rajasthan. Like any other industries units the SSIs, also having internal as well as external operations. In Rajasthan, it is estimated that about $40 \%$ of SSI units are sick industries. A large number of SSIs are found to be sick due to lack of working capital, raw materials and marketing facilities. The present study aim set to evaluate the working capital management problems of SSI in Rajasthan.

The present study is based on the secondary data collected from Annual Statistic Abstracts, Hand Books published by Directorate on Industries Rajasthan, census report of $3^{\text {rd }}$ All India Census of SSIs 2001-2002 conducted by Development Commissioner (SSI), Government of India, and Report published by RBI. The monthly Bulletins by RBI are also used for collecting data. Besides this, the Journals published by RBI are used for collecting data. Besides this the journals published by ICWA of India, ICA of India and ICFA of India have also been used to obtain data.

\section{Importance of Working Capital}

Every industry needs working capital to run the day-to-day business activities. Particularly in SSI, the enterprise is going to collapse without adequate supply of working capital. According to S.C.Kuchhal working capital is a business enterprises may be compared to the blood of the human body; blood gives life and strength to the business organisation*1. It has been pointed out by RBI that a firms profitability may be increase as more working capital is added to fixed capital provided the firm does not exceed cent present capacity*2. To examine the needs to working capital basically there are two types of Permanent as well as Temporary working capital. To examine the source of working capital there are three sources such as long term, short tern and transactionary source.

\section{Working Capital Management of SSI}

Working capital management is controlling and managing the current assets of a firm. Thus the working management for the short term, hence there is great need for efficient management of working capital, it is proposed in this chapter to deal with some of the crucial aspects of working capital, namely, size, growth, structure and efficiency with respect to the selected SSIs.

\subsection{Size of Working Capital}

Table (1) presents the information about the size of investment in working capital and its percentage to total assets in the SSIs of Rajasthan. It can be seen from the table that the investment in working capital (gross working capital i.e. current 
assets ) in absolute terms stood at Rs 3,742.24 lakh in 1996-97 and at Rs 4,216.79 lakhs in the year 2005-06, for all the enterprises taken together. In relatives, working capital, which average around $29.95 \%$ of total assets in the beginning of the study, came down to $26.85 \%$ by the year $2005-06$.

Table (2) shows the current assets of the five Industrial areas from the year 1996-97 to the year 2005-06.

Table (1) depicts that for all the SSIs the working capital has ranged between 23.66 (lowest in 1999-2K) to 29.95 (highest in 1996-97). Therefore, the variation computed by range method will be:

Range of Working Capital= Highest-Lowest

Range of Working Capital $=29.95-23.66=6.29 \%$

The coefficient of range $=($ Highest-Lowest $) /($ Highest + Lowest $)$

Coefficient of range $=6.23 /(29.95+23.66)=0.117=11.7$

The gross working capital as a percentage of total assets has fluctuated from year to year for all the SSI units during the period of study. There is no consistent trend of rise or fall in the quantum or percentage of working capital.

\subsection{Chart A: Showing Component of Assets}

Figure 1 is sub-divided bar diagram showing the total assets in each bar, which comprises of current assets and fixed or block assets. Series 1 depict current assets, series 2 depict fixed assets. It is the nature of small-scale industry that small entrepreneurs have less funds to block on fixed assets. From the chart it is clearly shown that small scale industries of Rajasthan heavily investing in current assets where as investment on fixed asset is comparatively low.

\subsubsection{Size of Current Assets}

The current assets of the 5 industrial are shown in absolute term. The figures in the parenthesis represent the current assets as a percentage of total assets of the selected units. Column 6 shows the year wise average of current assets of all the five industries estates. The last row of Table(2) showed the average current assets of each industrial estate over the year period of study. The ten year average of the five industrial estates has varied from between $41.64 \%$ to $45.75 \%$, showing a variation range of 4.11 , which is less than the variation for all the SSIs of the State. The main reason for variation for arisen due to the fact that the total universe (SSIs of the whole state) includes various types of industrial units, some requiring less and other requiring more current assets. The year wise average for all the selected industrial estates shows a lowest of $41.51 \%$ in the year $1998-99$ and a highest of $46.61 \%$ in the year $2005-06$ therefore, having a variation range of $5.10 \%$. The grand average year-wise and industry wise is $44.07 \%$, which shows that the selected units on an average have employed $44.07 \%$ of their total assets in current assets. Like the universe, there is no definite pattern of rise or fall in current assets of the selected units. On the contrary, the current assets have fluctuated over the period of study. This also shown that the firms do not have a policy of a constant working capital. The working capital fluctuates according to the requirement of the business or according to the availability of funds for this purpose.

\section{Growth of Current Assets}

Table (3) depicts the trends percentage of current assets growth in all the selected units. The percentage is competed with 1996-97 as base year. It is observed from the trends that in spite of fluctuation in the amount of current assets they have increased marginally during the period under study. The amount of current assets they have increased marginally during the period under study. The rise might have been due to the inflation factor. Since, all the units selected require different type of raw materials; it is not considered prudent to factories the inflation at a single rate. Because of different commodities have different inflation rate. Further, in certain cases the amount held in current assets may also change due to factors like efficiency/in-efficiency in management, demand for the products from 100 in $1996-97$ to 106.70 in 2005-06. Therefore, the net increase over the ten year period is 6.70 percent, which amounts to less than 1 percent per year. Figure 2 shows the trend line of the percentage of working capital over the period of study form 1996-97 to 2005-06.

\section{Industry Wise Size of Current Assets}

Table (4) depicts industry wise current assets (gross working capital) in the SSI units or Rajasthan. All the SSIs have been divided in to 12 broad categories viz. Food \& Allied, Chemical \& Allied, Electrical \& Electronics, Engineering \& Metal, Forest \& Wood, Glass \& Ceramics, Live Stock \& Leather, Paper \& Paper Product, Rubber \& Plastic Product, Textiles, Misc. Manufacturing, and Repairing \& Servicing. The Current assets of these industries have been shown separately for a period of five years i.e. from 2001-02 to 2005-06. The last column of the table shows the average current assets over the five years period. The table shows that investment in current assets in highest for Engineering \& Metal Based industry as well as for Forest \& Wood products industry. The total investment is lower for Repairing \& Servicing as well as Pater \& Paper Products, Rubbers \& Plastic Products. Over the five-year period of study, the investment is 
current assets have fluctuated in all the industries. There is no definite rising and falling trends. This means that the SSIs have more or less stagnated and have perhaps not taken any major expansion or growth plans. Based on survey made by a questionnaire, the respondents were asked about the percentage of investment in current assets i.e. current assets as a percentage of total assets in all the selected industries under the study. The table reveals that the percentage of current assets is highest in case of forest and wood products industry. From the 12 industries, the current assets are 50 percent or more in case of forest and wood based, Engineering \& Metal Based, Live Stock \& Leather and Textiles industry.

For all the remaining industries, the current assets are less than 50 percent of total assets. On the flip side, current assets are lowest in case of repairing \& servicing as well as food \& allies based industries. The huge investment in current assets in case of forest \& wood based as well as Engineering \& Metal Based industries is obvious because of the nature of such industries. They have to invest huge amounts in materials and other ingredients of inventory.

\section{Structure of Working Capital Components}

The composition of working capital and the relative importance of the ingredients are presented in table(6) and Figure 3. It can be seen from the table that the structure of working capital was dominated by inventories is most of the industries. From table (6) we observed that inventory component is about $77.42 \%$ in case of food and allied based industry. Followed by forest \& wood based industry where it is $63.24 \%$. On the other hand side, the inventory component is lower in case of repairing and servicing industry being $21.42 \%$ of total current assets, followed by miscellaneous manufacturing industry it is $33 \%$. Similarly, receivables are highest in case of textile industry being $51.52 \%$ followed by glass \& ceramics as well as live stock and leather where it is $50 \%$ in both the cases. The lowest receivables percentage wise are in case of food \& allied based industry followed by forest and wood industry. Cash \& Bank balance is highest in case of repairing \& servicing industry (being $28.51 \%$ ) followed by miscellaneous manufacturing $(21.21 \%)$. The lowest cash and bank balance is in case of chemical \& allied industry (2.94\%) followed by glass and chemical $3.85 \%$. As far as other current assets are concerned engineering \& metal industry has $1.15 \%$ on the lower side and glass \& ceramics has $7.69 \%$ on the higher side. There are no other current assets in livestock \& leathers, electrical and electronics, paper and paper products, rubber and plastic products.

Chart shows the composition of current assets for all the 98 units. Out of total investment of Rs 414 lakhs in current assets for all the 98 units, the inventory, receivable, cash and bank and other current assets components are $49.75 \%$, $35.99 \%, 10.63 \%$ and $6.23 \%$ respectively. The study reveals, that inventory component is a major component and constitutes almost $50 \%$ of the current assets.

\section{Component of Working Capital for Selected SSIs}

Average Components of working capital for selected SSIs of Rajasthan during the year 2005-06 shows in Figure 3. It is revealed from the chart that inventory and receivable jointly covers $84 \%$ of the total current assets. Whereas cash \& bank contain only $10 \%$.

\section{Effectiveness of Working Capital Management}

Effectiveness of working capital management can be judge with the help of Liquidity Ratios as well as Working Capital Turnover Ratio.

Liquidity ratios refer to the ratios which analysis the liquidity portion of the organisation because liquid is the highly required part of working capital. Basically there are two types of liquidity ratio such as Current Ratio and Liquid Ratio/Quick Assets Ratio/ Acid Test Ratio.

\subsection{Current Ratio}

It is to be calculating to examine the current assets position on current liabilities. It can be calculate as

Current Ratio $=$ Current Assets/Current Liabilities

\subsection{Liquid Ratio}

On the other hand, Liquid Ratio is to be calculated to examine the current payment situation where stock and prepaid expense is excluded in the current assets i.e. also called liquid/quick/acid-test assets. It can be calculated as under:

Liquid Ratio $=$ Liquid Assets/Current Liabilities or current Assets-Stock-Prepaid Expenses/Current Liabilities

Let us examine the important ratios of liquidity and activity of the selected SSI units of Rajasthan in table (7). The turnover of current assets, which indicates the frequency at which they were rotating, is an important measure of efficiency of working capital management of a unit. A low ratio reflects a slow movement of current assets thereby, implying a sub-optimal utilization of current assets. Judge against this standard, it can be observed form Table (3) that the SSIs were able to maintain a very low level of efficiency in the use of working capital due to very low turnover of 
current assets which remained almost constant (ranging between 3.44 to 3.58) during the five year period under investigation.

Working Capital Turnover Ratio is to be calculating the how much effect the working capital for the revenue; it can be calculated as under:

Working Capital Turnover $\mathrm{R}=$ Net Annual Sales/Average working Capital

As well as other turnover ratio can also be use to examine the working capital management such as:

1. Stock Turnover Ratio

2. Debtor Turnover Ratio

3. Creditor Turnover Ratio

4. Debtor collection period

5. Current Assets Turnover Ratio etc.

\section{Conclusion}

The study is undertaken by taking 5 years data from secondary source. From this study, it has been found the working capital management is to decide the pattern of financing of the current assets, which is one of the biggest problems of working capital management. The SSIs has to decide about the sources of funds, which can be avail to make investment in the current assets. The problem of working capital management of small scale industries is not new, it is prevailing in India. The SSI units are low capital base where investment on fixed assets found to be less. Without the help of government support and financial institutions co-operation, it is very difficult to solve the problem of working capital management of SSIs of Rajasthan in particular and of India in general.

\section{References}

Commissioner SSI Ministry of SSI. (2002). Report on second all India census of SSI Units 200-2002, Nirman Bhawan, New Delhi

Directorate of Economic and Statistics Directorate of Economic and Statistics. Fourth \& Fifth Economic Census

Directorate of Industries GOR. (2010). Progress Report of SSI for the year 2008-2009.

Industrial Potential Survey. (2009-2010). Dist-Industry Center, Jaipur Fourth Economic census 1998 Pub.

Instruction manual for Fourth Census of M.S.M.E.s 200-2007 (Statistics \& Data bank division, Dev. Commissioner SSI Ministry of SSI ,GOI, Nirman Bhawan, New Delhi)

Kuchhal, S. C. (1976). Corporation Finance Principals and Progress. Allahbad: Chaitanya publishing house, page 124.

Policy package for micro, small and medium enterprises. Government of Rajasthan Publication

Quick result third all India census of SSI 2001-2002. Dev. Commissioner SSI Ministry of SSI , GOI, Nirman Bhawan, New Delhi

RBI. Finance of medium and large public limited companies RBI bulletins, Page 9

Stastical abstracts of Rajasthan published by of published by Directorate of economic and statistics 2002 ,2006, 2008 respectively 
Table 1. Size of Investment

\begin{tabular}{|c|c|c|c|}
\hline Years & Total assets (Rs.) & Investment working capital (Rs.) & $\begin{array}{c}\text { Working capital } \\
\text { As \% of total assets }\end{array}$ \\
\hline $1996-97$ & $12,496.63$ & $3,742.24$ & 29.95 \\
\hline $1997-98$ & $14,706.41$ & $3,971.56$ & 27.00 \\
\hline $1998-99$ & $13,617.46$ & $3,587.29$ & 26.34 \\
\hline $1999-00$ & $16,293.82$ & $3,854.48$ & 23.66 \\
\hline $2000-01$ & $15,317.70$ & $4,046.16$ & 26.41 \\
\hline $2001-02$ & $16,565.68$ & $4,847.93$ & 29.26 \\
\hline $2002-03$ & $14,670.53$ & $4,123.38$ & 28.11 \\
\hline $2003-04$ & $17,829.64$ & $4,975.87$ & 27.91 \\
\hline $2004-05$ & $17,635.36$ & $4,327.16$ & 24.54 \\
\hline $2005-06$ & $16,672.74$ & $4,216.79$ & 25.29 \\
\hline Average \% Over 10 Years & & 26.85 \\
\hline
\end{tabular}

Rs. In Lakh

Source: Statistical cell, Directorate of industries, Rajasthan

Table 2. Size of Current Assets

\begin{tabular}{|c|c|c|c|c|c|c|}
\hline Years & $\begin{array}{c}\text { JHOTW } \\
\text { ARA }\end{array}$ & $\begin{array}{l}\text { SITAPU } \\
\text { RA }\end{array}$ & $\begin{array}{c}\text { MALVIYA } \\
\text { NAGAR }\end{array}$ & $\begin{array}{l}\text { MANSO } \\
\text { RAVER }\end{array}$ & VKI & $\begin{array}{c}\text { Total } \\
\% \text { age }\end{array}$ \\
\hline & 1 & 2 & 3 & 4 & 5 & 6 \\
\hline $1996-97$ & $\begin{array}{c}84 \\
(46.00)\end{array}$ & $\begin{array}{c}91 \\
(42.52)\end{array}$ & $\begin{array}{c}56 \\
(35.97)\end{array}$ & $\begin{array}{c}43 \\
(41.36)\end{array}$ & $\begin{array}{c}114 \\
(47.50)\end{array}$ & $\begin{array}{c}388 \\
(42.75)\end{array}$ \\
\hline $1997-98$ & $\begin{array}{c}87 \\
(47.54)\end{array}$ & $\begin{array}{c}90 \\
(42.45)\end{array}$ & $\begin{array}{c}59 \\
(37.82)\end{array}$ & $\begin{array}{c}39 \\
(37.50)\end{array}$ & $\begin{array}{c}109 \\
(45.17)\end{array}$ & $\begin{array}{c}384 \\
(42.09)\end{array}$ \\
\hline 1998-99 & $\begin{array}{c}79 \\
(43.17)\end{array}$ & $\begin{array}{c}93 \\
(43.87)\end{array}$ & $\begin{array}{c}53 \\
(33.97)\end{array}$ & $\begin{array}{c}42 \\
(40.38)\end{array}$ & $\begin{array}{c}111 \\
(46.25)\end{array}$ & $\begin{array}{c}378 \\
(41.51)\end{array}$ \\
\hline 1999-00 & $\begin{array}{c}83 \\
(45.36) \\
\end{array}$ & $87(41.10)$ & $\begin{array}{c}61 \\
(39.10) \\
\end{array}$ & $\begin{array}{c}46 \\
(44.23) \\
\end{array}$ & $\begin{array}{c}108 \\
(45.00) \\
\end{array}$ & $\begin{array}{c}385 \\
(42.95) \\
\end{array}$ \\
\hline 2000-01 & $\begin{array}{c}81 \\
(44.22)\end{array}$ & $\begin{array}{c}94 \\
(44.34)\end{array}$ & $\begin{array}{c}68 \\
(43.59)\end{array}$ & $\begin{array}{c}48 \\
(46.15)\end{array}$ & $\begin{array}{c}103 \\
(42.92)\end{array}$ & $\begin{array}{c}394 \\
(44.25)\end{array}$ \\
\hline 2001-02 & $\begin{array}{c}86 \\
(47.00)\end{array}$ & $\begin{array}{c}98 \\
(46.23)\end{array}$ & $\begin{array}{c}79 \\
(50.64)\end{array}$ & $\begin{array}{c}45 \\
(43.27)\end{array}$ & $\begin{array}{c}98 \\
(40.83)\end{array}$ & $\begin{array}{c}406 \\
(45.59)\end{array}$ \\
\hline $2002-03$ & $\begin{array}{c}81 \\
(44.26)\end{array}$ & $\begin{array}{c}95 \\
(44.81)\end{array}$ & $\begin{array}{c}82 \\
(52.56)\end{array}$ & $\begin{array}{c}41 \\
(39.42)\end{array}$ & $\begin{array}{c}105 \\
(43.75)\end{array}$ & $\begin{array}{c}404 \\
(44.96)\end{array}$ \\
\hline 2003-04 & $\begin{array}{c}87 \\
(47.54)\end{array}$ & $\begin{array}{c}95 \\
(44.81)\end{array}$ & $\begin{array}{c}80 \\
(51.28)\end{array}$ & $\begin{array}{c}44 \\
(42.31)\end{array}$ & $\begin{array}{c}104 \\
(43.33)\end{array}$ & $\begin{array}{c}410 \\
(45.55)\end{array}$ \\
\hline 2004-05 & $\begin{array}{c}84 \\
(46.00) \\
\end{array}$ & $\begin{array}{c}93 \\
(43.87) \\
\end{array}$ & $\begin{array}{c}81 \\
(51.92) \\
\end{array}$ & $\begin{array}{c}38 \\
(36.54) \\
\end{array}$ & $\begin{array}{c}102 \\
(42.50)\end{array}$ & $\begin{array}{c}398 \\
(44.57) \\
\end{array}$ \\
\hline $2005-06$ & $\begin{array}{c}85 \\
(46.45)\end{array}$ & $\begin{array}{c}96 \\
(45.28)\end{array}$ & $\begin{array}{c}83 \\
(53.21)\end{array}$ & $\begin{array}{c}47 \\
(45.19)\end{array}$ & $\begin{array}{c}103 \\
(42.50)\end{array}$ & $\begin{array}{c}414 \\
(46.61)\end{array}$ \\
\hline Average $\%$ & 45.75 & 43.97 & 45.01 & 41.64 & 44.02 & 44.07 \\
\hline
\end{tabular}

Rs. In crore

Note: The figure in parenthesis represents working capital as \% of total assets 
Table 3. Growth of Current Assets

\begin{tabular}{|c|c|c|}
\hline Years & $\begin{array}{c}\text { Actuals } \\
\text { (Rs. In lakhs })\end{array}$ & Trend \% \\
\hline $1996-97$ & 338 & 100 \\
\hline $1997-98$ & 384 & 98.97 \\
\hline $1998-99$ & 378 & 97.42 \\
\hline $1999-2 \mathrm{~K}$ & 385 & 99.23 \\
\hline $2000-01$ & 394 & 101.55 \\
\hline $2001-02$ & 406 & 104.12 \\
\hline $2002-03$ & 404 & 105.67 \\
\hline $2003-04$ & 410 & 105.67 \\
\hline $2004-05$ & 398 & 102.58 \\
\hline $2005-06$ & 414 & 106.70 \\
\hline
\end{tabular}

Table 4. Industry wise Current Assets

\begin{tabular}{|c|c|c|c|c|c|c|c|}
\hline \multirow{2}{*}{$\begin{array}{c}\text { S. } \\
\text { No. }\end{array}$} & $\begin{array}{c}\text { Types of } \\
\text { Industry }\end{array}$ & \multicolumn{5}{|c|}{ Years } & \multirow{2}{*}{ Average } \\
\cline { 3 - 7 } & $2001-02$ & $2002-03$ & $2003-04$ & $2004-05$ & $2005-06$ & \\
\hline 1 & Food \& Allied & 30 & 31 & 29 & 32 & 31 & 30.6 \\
\hline 3 & Chemical \& Allied & 34 & 28 & 35 & 31 & 34 & 32.4 \\
\hline 4 & Electrical \& Electronics & 22 & 24 & 27 & 24 & 25 & 24.4 \\
\hline 5 & Engineering \& Metal & 87 & 88 & 87 & 86 & 87 & 87 \\
\hline 6 & Forest \& Wood & 70 & 69 & 72 & 71 & 68 & 70 \\
\hline 7 & Glass \& Ceramics & 27 & 26 & 27 & 27 & 26 & 26.6 \\
\hline 8 & Live Stock \& Leather & 25 & 23 & 26 & 25 & 28 & 25.4 \\
\hline 9 & Ruber \& Paper Product & 14 & 15 & 17 & 16 & 18 & 16 \\
\hline 10 & Ruber \& Plastic Product & 17 & 19 & 18 & 17 & 17 & 17.6 \\
\hline 11 & Misc. Manufacturing & 36 & 30 & 32 & 31 & 33 & 30.4 \\
\hline 12 & Repairing \& Servicing & 13 & 13 & 14 & 12 & 14 & 13.2 \\
\hline & Total & 406 & 404 & 410 & 398 & 414 & 404.4 \\
\hline
\end{tabular}

Table 5. Current Assets as percentage of Total Assets

\begin{tabular}{|c|c|c|}
\hline S. NO. & Industry Type & $\%$ age \\
\hline 1 & Food and Allies Based & $25-30$ \\
\hline 2 & Chemical and Allied Based & About 30 \\
\hline 3 & Electrical \& Electronics Based & $35-40$ \\
\hline 4 & Engineering \& Metal Based & $50-60$ \\
\hline 5 & Forest and Wood Based & About 70 \\
\hline 6 & Glass and Ceramics & $40-50$ \\
\hline 7 & Live Stock \& Leather & About 50 \\
\hline 8 & Paper and Paper Products & $30-40$ \\
\hline 9 & Rubber and Plastic Products & About 30 \\
\hline 10 & Textiles & About 50 \\
\hline 11 & Misc. Manufacture & About 30 \\
\hline 12 & Repairing and Servicing & About 20 \\
\hline
\end{tabular}


Table 6. Industry wise Main Components of Current Assets of SSIs of Rajasthan for 2005-06

\begin{tabular}{|c|c|c|c|c|c|}
\hline $\begin{array}{c}\text { Components } \\
\text { (Industry) }\end{array}$ & Inventory & Receivables & Cash \& Bank & Others & Total \\
\hline Food \& Allied & $24(77.42)$ & $03(9.70)$ & $02(6.50)$ & $02(6.38)$ & $31(100)$ \\
\hline Chemicals \& Allied & $18(52.94)$ & $13(38.23)$ & $01(2.94)$ & $02(5.88)$ & $34(100)$ \\
\hline Electrical \& Electronics & $10(40)$ & $12(48)$ & $03(12)$ & - & $25(100)$ \\
\hline Engineering \& Metal & $45(51.72)$ & $35(40.22)$ & $06(6.90)$ & $01(1.15)$ & $87(100)$ \\
\hline Forest \& Wood Based & $43(63.24)$ & $08(11.76)$ & $12(17.65)$ & $05(7.35)$ & $68(100)$ \\
\hline Glass \& Ceramics & $10(38.46)$ & $13(50)$ & $01(3.85)$ & $02(7.69)$ & $26(100)$ \\
\hline Live stock \& Leather & $12(42.86)$ & $14(50)$ & $02(7.49)$ & - & $28(100)$ \\
\hline Paper \& Paper product & $10(55.55)$ & $07(41.18)$ & $02(7.49)$ & - & $17(100)$ \\
\hline Rubber \& Plastic products & $08(47.05)$ & $07(41.18)$ & $02(11.77)$ & - & $17(100)$ \\
\hline Textiles & $12(36.36)$ & $17(51.52)$ & $03(9.09)$ & $01(3.03)$ & $33(100)$ \\
\hline Misc. Manufacturing & $11(33.33)$ & $14(42.42)$ & $07(21.21)$ & $01(3.03)$ & $33(100)$ \\
\hline Repairing \& Servicing & $03(21.42)$ & $06(42.86)$ & $04(28.57)$ & $01(7.14)$ & $14(100)$ \\
\hline Total & $206(49.76)$ & $149(35.99)$ & $44(10.63)$ & $15(6.23)$ & $414(100)$ \\
\hline
\end{tabular}

The figures in the parenthesis represent the percentage of each ingredient.

Table 7. Current, Quick, Current Assets Turnover Ratios

\begin{tabular}{|c|c|c|c|}
\hline Year & Current Ratio & Quick Ratio & Current Assets Turnover Ratio \\
\hline $2001-02$ & $1.04: 1$ & $.501: 1$ & 3.44 Times \\
\hline $2002-03$ & $1.02: 1$ & $.491: 1$ & 3.48 Times \\
\hline $2003-04$ & $1.04: 1$ & $.514: 1$ & 3.44 Times \\
\hline $2004-05$ & $1.01: 1$ & $.514: 1$ & 3.58 Times \\
\hline $2005-06$ & $1.02: 1$ & $.514: 1$ & 3.48 Times \\
\hline
\end{tabular}

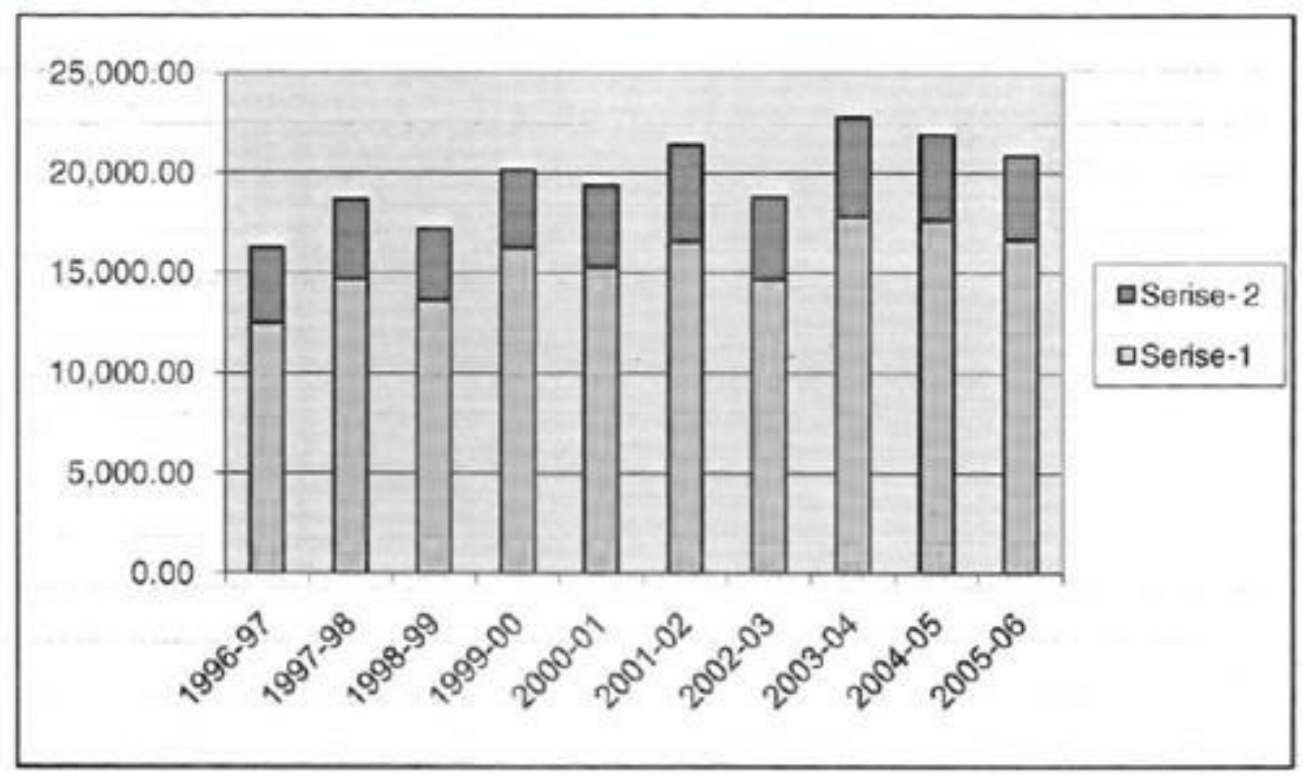

Figure 1. Size of Investment in Current: Asset vs Fixed Asset 


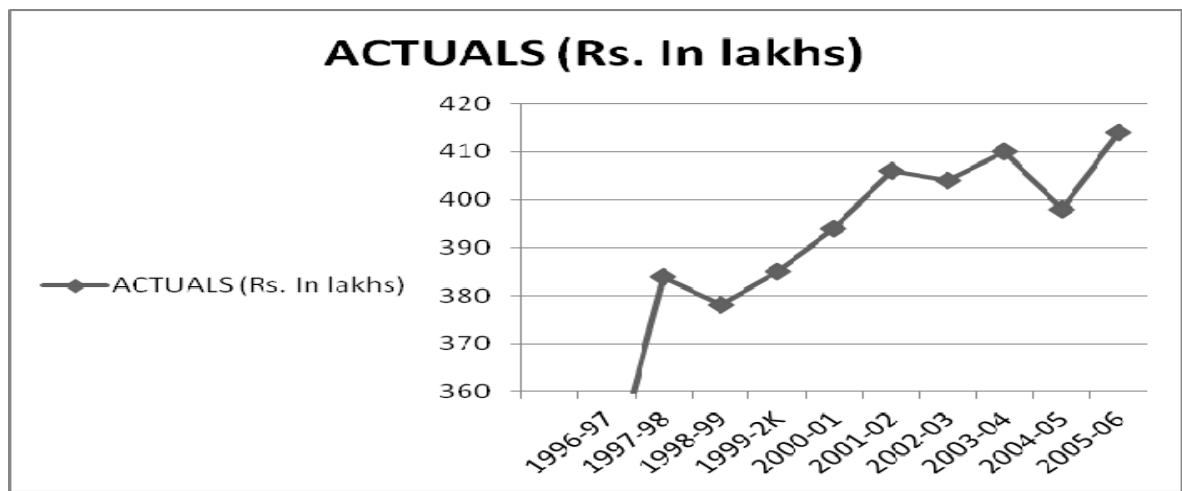

Figure 2

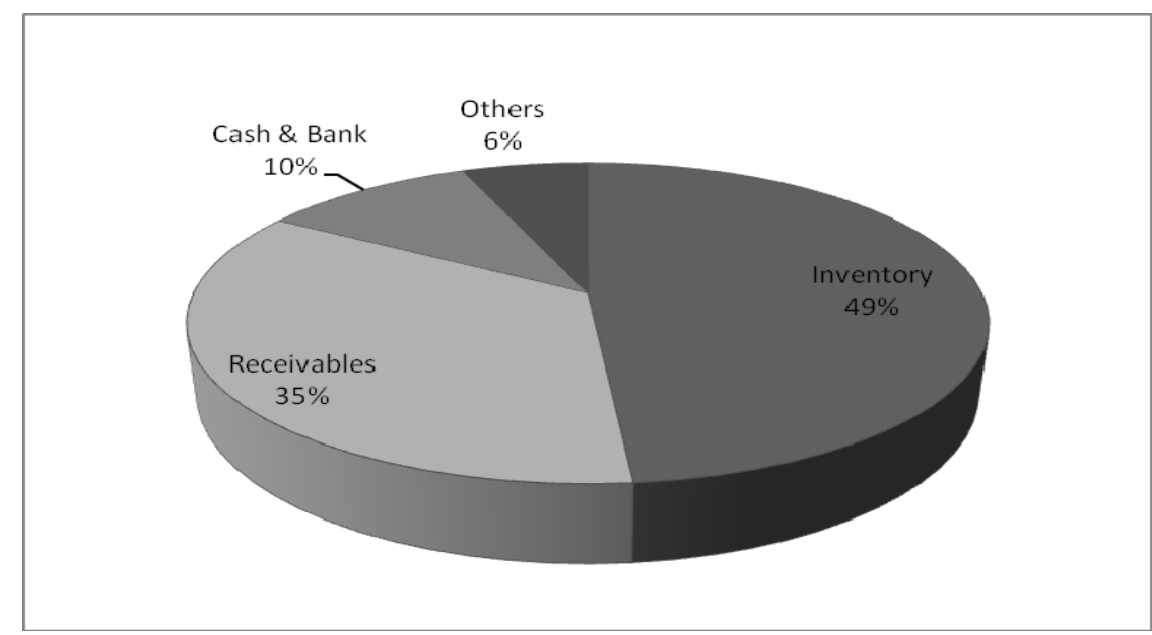

Figure 3. Component of working capital for selected SSIs in Rajasthan 2005-06

This chart shows the Structure of working capital for different industries of the sample units. The components of working capital in this chart are shown by subdivided bar diagram.

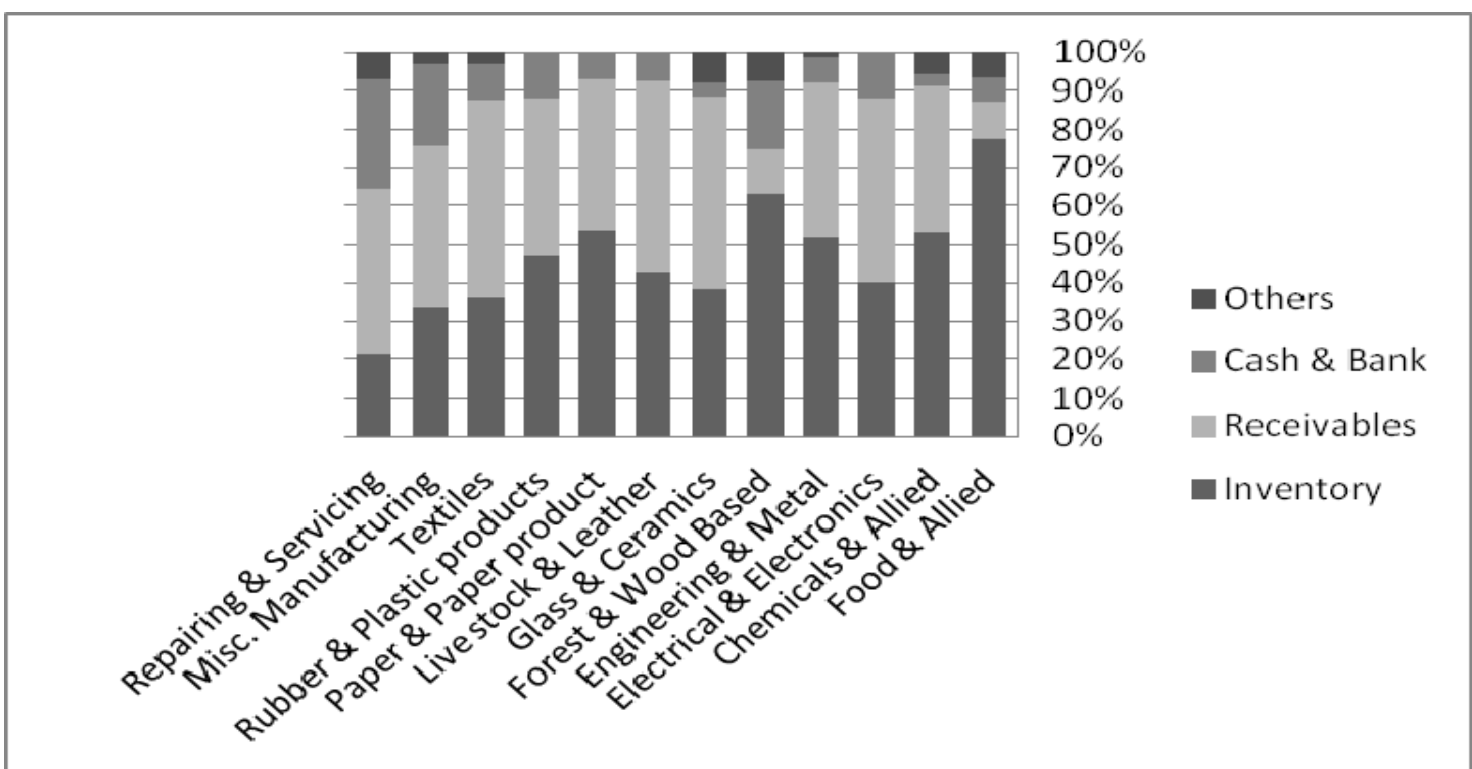

Figure 4. Average Components of working capital for different industries SSIs of Rajasthan 2005-06 This chart shows the structure of working capital for different industries of the sample unit. The component of working capital is, this chart are shown by subdivided bar diagram. 